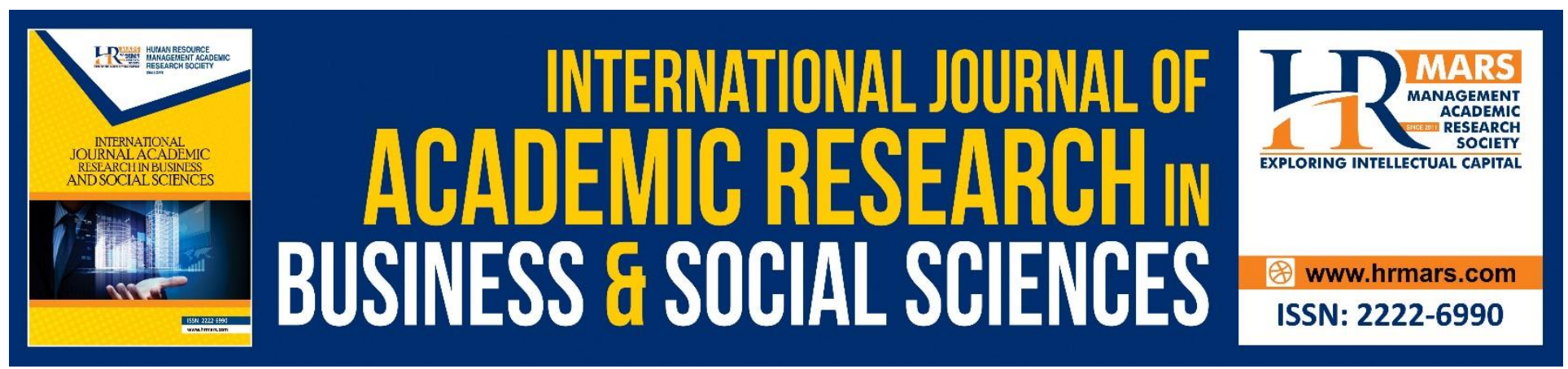

\title{
Systematic Risk Determinants of The Japanese Shipping Industry
}

Adeel Riaz, Ouyang Hongbing, Rafiq Mansoor

To Link this Article: http://dx.doi.org/10.6007/IJARBSS/v9-i1/5503 $\quad$ DOI: $10.6007 /$ IJARBSS/v9-i1/5503

Received: 13 Dec 2018, Revised: 19 Jan 2019, Accepted: 22 Jan 2019

Published Online: 25 Jan 2019

In-Text Citation: (Riaz, Hongbing, \& Mansoor, 2019)

To Cite this Article: Riaz, A., Hongbing, O., \& Mansoor, R. (2019). Systematic Risk Determinants of The Japanese Shipping Industry. International Journal of Academic Research in Business and Social Sciences, 9(1), 10301042.

Copyright: (C) 2019 The Author(s)

Published by Human Resource Management Academic Research Society (www.hrmars.com)

This article is published under the Creative Commons Attribution (CC BY 4.0) license. Anyone may reproduce, distribute, translate and create derivative works of this article (for both commercial and non-commercial purposes), subject to full attribution to the original publication and authors. The full terms of this license may be seen at: $\underline{\text { http://creativecommons.org/licences/by/4.0/legalcode }}$

Vol. 9, No. 1, 2019, Pg. 1030 - 1042

http://hrmars.com/index.php/pages/detail/IJARBSS

JOURNAL HOMEPAGE

Full Terms \& Conditions of access and use can be found at http://hrmars.com/index.php/pages/detail/publication-ethics 


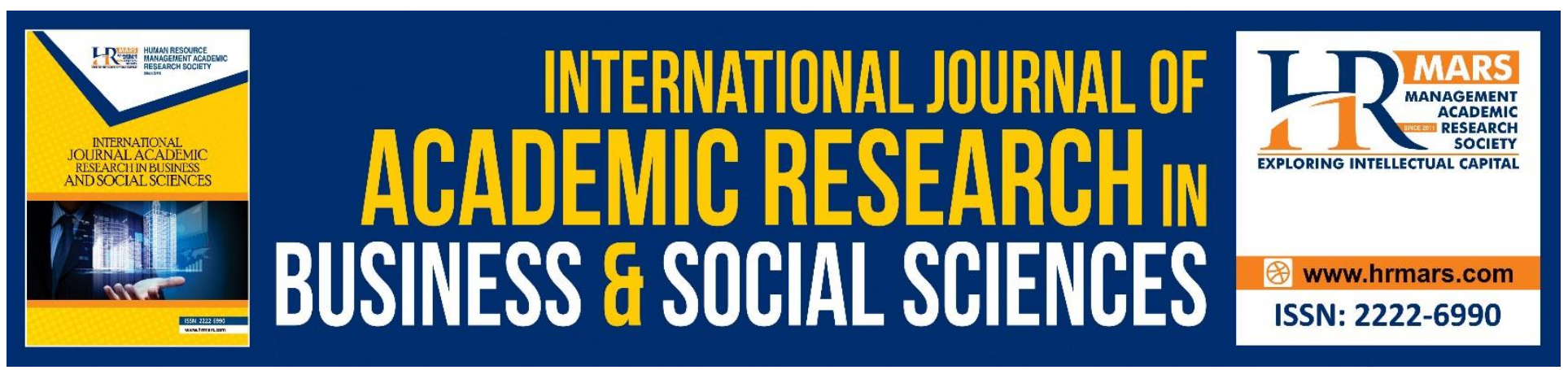

\title{
Systematic Risk Determinants of The Japanese Shipping Industry
}

\author{
Adeel Riaz ${ }^{1}$, Ouyang Hongbing, Rafiq Mansoor \\ School of Economics, Huazhong University of Science and Technology, Wuhan, P.R. China \\ ${ }^{1}$ Corresponding author: riazadeel46@yahoo.com
}

\begin{abstract}
This study investigates whether financial variables account for the variation in systematic risk of Japanese shipping firms. Results from Japanese shipping firms listed on Tokyo stock exchange for the period 2000-2017 indicate that the main determinants of systematic risk are firm size and operating efficiency. Moreover, it turns out that firm size is positively related to systematic risk while operating efficiency is equally important and is negatively associated with systematic risk. Our evidence on systematic risk indicates that systematic risk of Japanese shipping industry is lower than overall market. Liquidity, growth, profitability and financial leverage are found to be insignificant in case of Japanese shipping firms. The results have important implications for managers and investors in policy making and investing to better manage and hedge the risks associated with shipping sector.
\end{abstract}

Keywords: Systematic Risk, Shipping Industry, CAPM, Japanese Shipping Industry

\section{Introduction}

Importance of shipping industry cannot be refuted as it is an important source of transportation and trade for centuries. Shipping industry is a highly volatile industry (Drobetz, Menzel, \& Schröder, 2016a; Kalouptsidi, 2014) and is highly affected by the global demand of goods. Apart from the global demand risk, there are risks specific to the shipping companies called systematic risk. Shipping industry relies on financial institutions in order to lease and expand its business ventures since running a shipping firm requires a lot of capital. Although systematic risk is non-diversifiable but by knowing the relationship between systematic risk and its influencing factors, it can be managed and an early judgment can be beneficial for investors and managers.

Systematic risk is measured by beta coefficient and is widely used by analysts and researchers. In case of Capital Asset Pricing Model (CAPM) and its descendants like ICAPM and multifactor asset pricing model, beta is used as the main determinant for stock's returns. Beta reflects a company's incremental business risk and measures systematic risk or undiversifiable risk in case of CAPM. Although shipping is a vital sector of an economy but it had been barely studied in context of asset pricing models. According to CAPM, investors are concerned about systematic risk which is undiversifiable rather than other risks which can be minimized by holding a diversified portfolio. 
Fama and French( 1997) found that determinants of systematic risk vary across industries. Various researchers have examined the relationship between systematic risk and accounting variables across different industries (Beaver \& Manegold, 1975; Hamada, 1972; Jarvela, Kozyra, \& Potter, 2009; Logue \& Merville, 1972). Beaver and Manegold (1975) identified that accounting variables can be used as a proxy to measure risk of stock returns.

A less extensive yet still significant amount of research has studied determinants of systematic risk across different industries. However, shipping industry, which is an important industry, have hardly been studied particularly at country level in context of systematic risk. Drobetz, Schilling and Tegtmeier(2010) was of the view that risk return profile of shipping is different across country and industry so it has potential to be treated as a separate asset class. Also, shipping industry has shifted from asset backed finance during 1980's to draw fund from public. So, it is important to study the determinants of systematic risk in case of shipping as it can help financial manager to reduce their risk, invest in profitable investments and diversify across industries.

Kavussanos, Juell-Skielse, and Forrest, (2003) use market model to estimate beta for shipping industry. They also found that beta is small for shipping industry as compared to other industries. Drobetz et al. (2010) also found shipping industry beta to be different than other industries. J.S. Lee and Jang (2007) estimate CAPM beta for airline industry to investigate firm specific variables and their relationship with systematic risk.

Current study has attempted to incorporate shipping companies listed on Tokyo Stock Exchange. Using panel regression methodology including firm specific financial variables we analyze relative influence of these factors on systematic risk. Our findings suggest that managers and investors should consider these financial factors while managing and investing in shipping firms to reduce risk and enhance firm's value.

The remainder of the paper is structured as follows. In section 2, we align our work with the relevant literature by segregating into financial variables used in our study. Section 3 presents data and methodology. In Section 4, we present results and discussion and section 5 concludes the paper.

\section{Literature Review}

\section{Systematic Risk}

Systematic risk occurs when investors are unable to fully diversify their risks and is estimated using CAPM (capital asset pricing model). Systematic risk in CAPM is denoted by beta( $\beta)$ and is a major determining factor of expected stock returns in CAPM(Lintner, 1965; Sharpe, 1964), and ICAPM also called intertemporal CAPM(Merton, 1974).

Beaver and Manegold (1975) were the first to study the relationship between beta (a measure of systematic risk and accounting information. Numerous researchers have identified the relationship between beta and accounting information in order identify the variables responsible for risk in a firm (Brimble \& Hodgson, 2007; Campbell, Polk, \& Vuolteenaho, 2010; Elgers \& Murray, 1982; Karpik \& Belkaoui, 1989).

Fama and French (1997) suggested that systematic risk and its determinants may vary substantially across industries. Kavussanos, Juell-Skielse and Forrest (2003) studied whether shipping industry's systematic risk is different than market and across industries and used CAPM- $\beta$ to measure systematic risk of shipping industry. In case of CAPM- $\beta$, systematic risk of each security is measured 
by sensitivity to change in the market portfolio.(Breen and Lerner 1973) argued that beta calculated by CAPM equation provides unbiased and consistent information. Using historical, data beta can be well predicted and is a valid measurement for systematic risk of a security (Beaver and Manegold, 1975; Logue and Merville, 1972). Beta can also help managers and investors to identify a firm's investment, operating and financial strategies and the extent to which macroeconomic factors affect firm (Logue and Merville, 1972).

Bos and Newbold (1984) argue that changes in macroeconomic and microeconomic factors affect systematic risk. Good economic conditions lead to lower beta while a higher beta is observed during poor global business conditions. Shipping is a highly volatile industry (Drobetz, Menzel, and Schröder, 2016b; Greenwood and Hanson, 2015) so its systematic risk varies according to global economic conditions. Campbell and Mei (1993) observed a higher beta for cyclical industries due to higher fluctuations in their cash flows.

In order to investigate Interrelationship between systematic risk and firm characteristics different number of financial variables have been selected. Jarvela, Kozyra, and Potter(2009); Logue and Merville(1972); and Melichar, (2016) chose seven, twenty-six and five financial variables respectively. In our panel regression model, most commonly used financial variables namely liquidity, growth, firm size, leverage, profitability and operating efficiency have been chosen in order to study the relationship between systematic risk and firm's intrinsic factors.

\section{Liquidity}

Beaver and Manegold (1975) found cash as the most liquid asset and were of the view that current assets have expected return of zero if we ignore purchasing power parity. Liquidity represents a firm's ability to repay its debts and is measured by ratio of current assets and current liabilities. A higher liquidity enables a firm to manage financial needs and budget fluctuations (Kim, Gu, and Mattila, 2002; J.S. Lee and Jang, 2007). There are diverse opinions regarding the relationship between liquidity and systematic risk. It is argued that current assets lower volatile stock returns which results in lower systematic risk of an asset. In our model current ratio (current assets/current liabilities) is used as a proxy to check the effect of liquidity on systematic risk of shipping.

\section{Growth}

A company's growth is measured by growth in its assets and revenues. Numerous empirical studies have found a positive relationship between growth and systematic risk(Logue \& Merville, 1972). A change in earnings before interest and taxes(EBIT) is used as a proxy to measure growth (J.-S. Lee \& Jang, 2007). Since EBIT growth is associated with higher future cash flows and as a result stock price also increases (Borde, 1998). However, Roh (2002) argued that a higher growth in EBIT makes it difficult for a firm to manage its resources required and leads to higher systematic risk. C. H. Lee Hooy (2012) employed five factor model on airline industry and found a negative relationship between earnings growth and systematic risk.

\section{Firm Size}

A larger firm size is thought to make a firm less risky on the ground that larger firms are better able to diversify their business and therefore risk. This lower risk also reduces the probability of 
bankruptcy(Titman and Wessels, 2018). Ang, Peterson and Peterson (1985) argued that economies of scale help bigger firms to lower their cost of production resulting in higher profits and consequently decreasing risks. Firm size has explanatory power for stock returns and firm size is significant no matter beta is included in the regression or not. Numerous studies have shown that there exists negative relationship between firm size and systematic risk. However, the relationship between firm size and risk had been inconclusive. Some studies argue that there exist negative relationship between a firm's size and beta (Ang et al., 1985; Breen and Lerner, 1973). Logue and Merville (1972) found positive relationship between airlines 'stock and systematic risk. On the contrary, Bowman (2018) was of the view that a firm size does not have any relationship with systematic risk since an expansion in firm's business is not related to capital structure rather financial leverage because of expansion affects risk. Marketable securities of larger firms make them less prone to risk since higher liquidity is associated with lower systematic risk (Fisher, 1959).

\section{Debt Leverage}

Debt leverage is used to measure a firm's ability to meet its obligations and if a company has debt in its capital structure it is referred to as a leverage company (Ross, Westerfield, and Jordan, 2009). Baggs and Brander (2006) measured financial leverage as a ratio of total liabilities to total assets and it is used as a proxy of financial leverage in our study. Modigliani and Miller (1963) found companies with higher leverage tend to be riskier. Beta as an increasing function of leverage was found by (Hong and Sarkar, 2008). In empirical studies a positive relation has been observed between risk and debt leverage (Amit and Livnat, 1988; Beaver and Manegold, 1975; Hsu and Jang, 2008; Kim et al., 2002; J.-S. Lee and Jang, 2007; Logue and Merville, 1972). Shipping industry relies heavily on financing and therefore exhibits high operating and financial leverage (Drobetz, Gounopoulos, Merikas, and Schröder, 2013). Hamada (1972) investigated that a firm will have a higher beta if it has higher financial leverage even if other company is in same risk class.

\section{Profitability}

Damitio and Schmidgall (2006) identified profitability as an ability of a firm to generate net income while controlling costs. Return on assets(ROA) is used as a proxy to measure profitability of a firm (Baggs and Brander, 2006). A higher profitability is associated with a lower probability of default or systematic risk of a firm (Logue and Merville, 1972). Although, a firm's profitability lowers its systematic risk but researchers argued that it differs across industries. Logue and Merville (1972) studied 287 companies during 1966 to 1970 and identified a negative relationship between profitability and systematic risk. A negative relationship was also found in case of restaurant and airline industry (Borde, 1998; J.-S. Lee and Jang, 2007). However, in case of financial industry higher profitability indicates that a firm is taking more risk (Borde, Chambliss, and Madura 1994). Therefore, a negative relationship is expected between profitability and systematic risk.

\section{Operating Efficiency}

Operational efficiency is represented by a ratio of sales and a given level of total assets or fixed assets. In our study ratio of sales to total assets is used which is revenue created per dollar of assets and is also called asset turnover ratio. J.-S. Lee and Jang (2007) used the same ratio in order to study 
systematic risk determinants in case of US airline industry and found a positive relationship between the two. However, (Logue and Merville, 1972) found negative relationship between operating efficiency and systematic risk. He was of the view that a higher operating efficiency leads to higher profitability which decreases systematic risk of a firm. By examining 35 casino firms (Kim et al., 2002) also found negative relationship between systematic risk and operating efficiency. Since shipping industry is more similar to airline industry so we hypothesize a positive relationship between systematic risk in Japanese shipping and operating efficiency.

\section{Data and Methodology}

The empirical study is performed on publicly listed shipping companies on Tokyo Stock Exchange during the period 2000-2017. This period was chosen because it encompassed many business cycles including financial crisis of 2007. Data for the shipping firms was obtained from Osiris. Financial researchers have traditionally used Capital Asset Pricing Model (CAPM) in order to calculate systematic risk of firms. In case of shipping industry, (Drobetz et al., 2016b; Kavussanos et al., 2003) used CAPM beta to investigate risks in shipping industry. J.-S. Lee \& Jang, (2007) used CAPM beta in order to study the relationship between airline stock's beta and financial variables. Beta is estimated by regressing a firm's monthly stock returns against market return (TOPIX). Monthly stock returns were obtained using the following expression

$$
R_{i . t}=\ln \left(P R I C E_{i, t} / P R I C E_{i, t-1}\right)
$$

Where $P R I C E_{i, t}$ is the price of a firm i stock's price at time t while $P R I C E_{i, t-1}$ will be price of a firm i for the previous period i.e. $\mathrm{t}-1$. Yearly beta for all the companies included in the sample are estimated by using linear regression analysis given as

$$
\text { Rit }=\alpha_{i}+\beta_{i} R_{m t}+\varepsilon_{i t}
$$

Where $R_{i t}$ denotes the return of asset $\mathrm{i}$ and $R_{m t}$ denotes market returns for period t. $\alpha_{i}$ is intercept and $\beta_{1}$ is the estimated yearly beta.

To investigate the relationship between systematic risk, measured as beta, and the variables influencing beta, a panel regression of annual betas with annual independent variables is carried out covering 18-years period.

$$
\beta_{i t}=\alpha_{0}+\alpha_{1} C R+\alpha_{2} \text { Growth }+\alpha_{3} T A+\alpha_{4} D T A+\alpha_{5} R O A+\alpha_{6} N A T
$$

Where $\beta_{i t}$ is systematic risk of a shipping firm i at time t. Description of variables in Error! Reference source not found. 
INTERNATIONAL JOURNAL OF ACADEMIC RESEARCH IN BUSINESS AND SOCIAL SCIENCES

Vol. 9, No. 1, Jan, 2019, E-ISSN: 2222-6990 (C) 2019 HRMARS

Table 1. Variables and Description

\begin{tabular}{|l|l|l|}
\hline Variable & Description & Measurement \\
\hline Beta & Systematic Risk & $\begin{array}{c}=\text { covariance (Return of } \\
\text { Asset, Return of } \\
\text { Market)/Variance } \\
\text { (Return of Market) }\end{array}$ \\
\hline CR & Current Ratio & $\begin{array}{l}\text { Current Assets/Current } \\
\text { Liabilities }\end{array}$ \\
\hline Growth & Growth in EBIT & $\left.=\left(\frac{(E B I T)_{t}-E B I T_{t-1}}{E B I T_{t}}\right) 100\right)$ \\
\hline TA & Total Assets & $=$ LOG (Total Assets) \\
\hline DTA & $\begin{array}{l}\text { Debt to Total } \\
\text { Assets Ratio }\end{array}$ & $=$ Debt/Total Assets \\
\hline ROA & Return on Assets & $=$ Sales/Total Assets \\
\hline NAT & $\begin{array}{l}\text { Net Assets } \\
\text { Turnover }\end{array}$ & $=$ Net Assets/Sales \\
\hline & &
\end{tabular}

Table 2 provides descriptive statistics of the financial variables. Fluctuations in growth in EBIT are because of including periods of financial crisis. Since shipping industry suffered heavy losses during financial crisis. On the contrary, shipping industry was enjoying super normal profits before the financial crisis so a greater volatility has been observed in case of growth in EBIT. Beta values, a measure of systematic risk, are below 1 which indicates that Japanese shipping industry's mean beta is lower than average beta of 1 of the market. Kavussanos et al., (2003) also found shipping industry's beta lower than market beta.

Table 2. Descriptive Statistics

\begin{tabular}{|l|r|r|r|r|}
\hline Variable & \multicolumn{1}{l|}{ Mean } & \multicolumn{1}{l|}{ Std. Dev. } & \multicolumn{1}{l|}{ Min } & \multicolumn{1}{l|}{ Max } \\
\hline Beta & 0.663282 & 0.816503 & -1.159 & 3.937962 \\
\hline CR & 1.18913 & 0.643542 & 0.36 & 4.38 \\
\hline Growth & -14.7083 & 169.8745 & -937.41 & 840.17 \\
\hline TA & 13.36705 & 1.699299 & 10.84857 & 17.06719 \\
\hline DTA & 0.471569 & 0.167411 & 0.070964 & 0.815967 \\
\hline ROA & 1.65807 & 3.323444 & -13.34 & 14.85 \\
\hline NAT & 1.231926 & 0.640941 & 0.19 & 4.32 \\
\hline
\end{tabular}

To verify integrated properties of all the variables, we apply (Levin, Lin, \& Chu, 2002) panel based unit root test. The results reported in table 3 clearly reveal that all variables are stationary at level. 
INTERNATIONAL JOURNAL OF ACADEMIC RESEARCH IN BUSINESS AND SOCIAL SCIENCES Vol. 9, No. 1, Jan, 2019, E-ISSN: 2222-6990 (C) 2019 HRMARS

Table 3. Unit Root Test

\begin{tabular}{|l|l|l|l|l|}
\hline Variable & Method & Statistic & Prob. & Obs \\
\hline Beta & Levin, Lin \& Chu t* & -4.76468 & $0.0000^{* * *}$ & 299 \\
\hline CR & Levin, Lin \& Chu t* & -3.44731 & $0.0003 * * *$ & 268 \\
\hline Growth & Levin, Lin \& Chu t* & -7.11677 & $0.0000^{* * *}$ & 259 \\
\hline TA & Levin, Lin \& Chu t* & -2.6437 & $0.0041^{* * *}$ & 271 \\
\hline DTA & Levin, Lin \& Chu t* & -2.58698 & $0.0048 * * *$ & 267 \\
\hline ROA & Levin, Lin \& Chu t* & -8.42683 & $0.0000^{* * *}$ & 275 \\
\hline NAT & Levin, Lin \& Chu t* & -3.26961 & $0.0005^{* * *}$ & 281 \\
\hline
\end{tabular}

Note: Significant at $* * * 1 \%$ level $* * 5 \%$ level and $* 10 \%$ level

Table 4 shows the Pearson correlation coefficient matrix among the variables. In case of Pearson test correlation is higher if it is above $\mathbf{0 . 8}$ in absolute value. Current ratio includes current debt in its measurement so a higher correlation is observed among current ratio and debt to assets ratio.

Table 4 Correlation Matrix for selected variables

\begin{tabular}{|l|r|r|r|r|r|r|r|}
\hline & \multicolumn{1}{l|}{ Beta } & \multicolumn{1}{l|}{ CR } & Growth & TA & DTA & ROA & NAT \\
\hline Beta & 1 & & & & & & \\
\hline CR & -0.0334 & 1 & & & & & \\
\hline Growth & 0.0887 & 0.0736 & 1 & & & & \\
\hline TA & 0.2638 & -0.1832 & -0.0505 & 1 & & & \\
\hline DTA & 0.1087 & -0.6552 & -0.1092 & 0.0574 & 1 & & \\
\hline ROA & 0.1019 & 0.1896 & 0.0401 & 0.0172 & -0.3156 & 1 & \\
\hline NAT & -0.2553 & -0.14 & -0.0148 & -0.2311 & -0.1782 & 0.0709 & 1 \\
\hline
\end{tabular}

Note: A "high" correlation is correlation greater than 0.8 in absolute value

\section{Results and Discussion}

We conduct Hausman test to choose appropriate method for our panel data. The Hausman (FE vs. $\mathrm{RE}$ ) test indicates that random effects results are preferred over fixed effects. Now that we have established that a regression with random effects is the most suitable method for our model, we estimate the model. 
INTERNATIONAL JOURNAL OF ACADEMIC RESEARCH IN BUSINESS AND SOCIAL SCIENCES Vol. 9, No. 1, Jan, 2019, E-ISSN: 2222-6990 @ 2019 HRMARS

Table 5. Regression Results

\begin{tabular}{|l|r|r|r|}
\hline beta & Coef. & \multicolumn{1}{l|}{ Std.Err. } & \multicolumn{1}{l|}{ Prob. } \\
\hline CR & 0.040969 & 0.129251 & 0.751 \\
\hline Growth & 0.000267 & 0.000235 & 0.256 \\
\hline TA & 0.159047 & 0.05183 & $0.002^{* * *}$ \\
\hline DTA & -0.26728 & 0.533033 & 0.616 \\
\hline ROA & 0.017892 & 0.012748 & 0.16 \\
\hline NAT & -0.25645 & 0.112474 & $0.023^{* * *}$ \\
\hline Constant & -1.10876 & 0.923346 & 0.23 \\
\hline
\end{tabular}

Note: Significant at $* * * 1 \%$ level $* * 5 \%$ level and $* 10 \%$ level

In what follows we interpret the results from our regression. A positive, although insignificant, relationship is found between liquidity and systematic risk. The positive sign can be explained by Jensen's(1986) theory of agency cost and a higher liquidity also indicates a firm's inability to invest cash in alternate profitable investments. As hypothesized growth in EBIT decreases systematic risk but in case of Japanese shipping companies the relationship is similar to financial companies. It also implies that Japanese shipping companies are risk takers and relies heavily on credit in order to maintain their earnings. Maintenance of earnings by leveraging increases systematic risk as in case of Japanese shipping companies. It is pertinent to note that there exists a positive relationship between firm size, measured by total assets, and systematic risk. This result is inconsistent with the previous studies that firm size and systematic risk are negatively associated. Empirically many researchers argue that larger firms are better able to diversify risk and are better prepared to overcome the impact of macro-economic changes. This increase in systematic risk in case of bigger firms is associated with lower global demand after the financial crises of 2008. Bigger shipping firm were affected severely after the financial crises because of high leverage and bankruptcy risk. Some of the biggest shipping companies either merged or went bankrupt after the financial crisis. Park and Kim (2016) also found a positive relationship between size and systematic risk in case of U.S. restaurant industry. Debt ratio is negatively associated with beta indicating that higher debt levels reduces firm risk. As described in earlier sections, shipping industry heavily relies on debt and equity financing. Firms with lower risks have more access to debt than riskier firms. Return on assets indicates how efficient a shipping company's management is using its assets to generate income and is insignificant in our analysis. In case of turnover, results are consistent with (Logue and Merville 1972). We found asset's turnover significant and negatively associated with systematic risk as found by (Gu and Kim 2002). This indicates that firms' higher efficiency in using assets to generate returns which help in depressing risk of Japanese shipping firms. Since shipping is highly competitive industry and using assets more efficiently can be a competitive advantage for firms. Japanese shipping firms should focus more on using existing fleet more efficiently. Since operational cost in shipping sector is higher hence it is better to operate current fleet more efficiently rather than expanding fleet which increases cost to the firms. Expansion of shipping firms also puts additional pressure by increasing its debt burden. 


\section{Conclusion}

One of the main objectives of firms is the coherence of profit maximization and lowering risk. A study of risks associated with businesses help managers and investors to mitigate, hedge and manage their risks. The aim of this paper has been to investigate systematic risk determinants of Japanese shipping firms. We show that shipping firms should consider extra burden of debt while expanding. Furthermore, firms should improve their operational efficiency with the assets they currently own. Oil is one the major operational expense for shipping industry. In order to increase operational efficiency firms should hedge their fuel costs. Extra care should be taken while expanding shipping business specially in a volatile environment. The findings of the current study are quite different from previous studies in case of firm size. It is because of specific characteristics of shipping industry. This study supports the argument that during economic downturns larger firms have to bear more fixed cost than smaller firms. Larger firms also suffered during financial crisis because of lower global demand. It is common in shipping industry to order new ships by looking at future domestic or global demand. But bigger firms have to bear severe consequences in case of economic downturns. The fact should be taken into account and management's policies be aimed at expansion by increasing firm's value. As for the investment decisions, investors should consider contribution of oil price in the systematic risk by lowering operating efficiency. Future studies should include other proxies for the variables to increase explanatory power. 
INTERNATIONAL JOURNAL OF ACADEMIC RESEARCH IN BUSINESS AND SOCIAL SCIENCES

Vol. 9, No. 1, Jan, 2019, E-ISSN: 2222-6990 @ 2019 HRMARS

\section{References}

Amit, R., \& Livnat, J. (1988). Diversification, Capital Structure, and Systematic Risk: An Empirical Investigation. Journal of Accounting, Auditing \& Finance.

Ang, J., Peterson, P., \& Peterson, D. (1985). Investigations into the Determinants of Risk: A New Look. Quarterly Journal of Business and Economics, 24(1), 3-20. Retrieved from http://www.jstor.org/stable/40472802

Baggs, J., \& Brander, J. A. (2006). Trade liberalization, profitability, and financial leverage. Journal of International Business Studies, 37(2), 196-211.

Beaver, W., \& Manegold, J. (1975). The Association Between Market-Determined and AccountingDetermined Measures of Systematic Risk: Some Further Evidence. The Journal of Financial and Quantitative Analysis, 10(2), 231.

Borde, S. F. (1998). Risk Diversity Across Restaurants: An Empirical Analysis. Cornell Hotel and Restaurant Administration Quarterly, 39(2), 64-69.

Borde, S. F., Chambliss, K., \& Madura, J. (1994). Explaining variation in risk across insurance companies. Journal of Financial Services Research, 8(3), 177-191.

Bos, T., \& Newbold, P. (1984). An Empirical Investigation of the Possibility of Stochastic Systematic Risk in the Market Model. Journal of Business.

BOWMAN, R. G. (1979). The Theoretical Relationship Between Systematic Risk and Financial (Accounting) Variables. The Journal of Finance, 34(3), 617-630.

Breen, W. J., \& Lerner, E. M. (1973). CORPORATE FINANCIAL STRATEGIES AND MARKET MEASURES OF RISK AND RETURN. The Journal of Finance, 28(2), 339-351.

Brimble, M., \& Hodgson, A. (2007). Assessing the risk relevance of accounting variables in diverse economic conditions. Managerial Finance.

Campbell, J. Y., \& Mei, J. (1993). Where do betas come from? Asset price dynamics and the sources of systematic risk. Review of Financial Studies.

Campbell, J. Y., Polk, C., \& Vuolteenaho, T. (2010). Growth or glamour? Fundamentals and systematic risk in stock returns. Review of Financial Studies.

Damitio, J. W., \& Schmidgall, R. S. (2006). A Re-Examination Of Key Managerial Accounting Skills For Lodging Industry Managers. The Journal of Hospitality Financial Management, 14(1), 35-41.

Drobetz, W., Gounopoulos, D., Merikas, A., \& Schröder, H. (2013). Capital structure decisions of globally-listed shipping companies. Transportation Research Part E: Logistics and Transportation Review, 52, 49-76.

Drobetz, W., Menzel, C., \& Schröder, H. (2016a). Systematic risk behavior in cyclical industries: The case of shipping. Transportation Research Part E: Logistics and Transportation Review, 88, 129145.

Drobetz, W., Menzel, C., \& Schröder, H. (2016b). Systematic risk behavior in cyclical industries: The case of shipping. Transportation Research Part E: Logistics and Transportation Review, 88, 129145.

Drobetz, W., Schilling, D., \& Tegtmeier, L. (2010). Common risk factors in the returns of shipping stocks. Maritime Policy and Management, 37(2), 93-120.

Elgers, P. T., \& Murray, D. (1982). The Impact of the Choice of Market Index on the Empirical Evaluation of Accounting Risk Measures. Accounting Review. 
INTERNATIONAL JOURNAL OF ACADEMIC RESEARCH IN BUSINESS AND SOCIAL SCIENCES

Vol. 9, No. 1, Jan, 2019, E-ISSN: 2222-6990 @ 2019 HRMARS

Fama, E. F., \& French, K. R. (1997). Industry costs of equity. Journal of Financial Economics, 43(2), 153-193.

Fisher, L. (1959). Determinants of Risk Premiums on Corporate Bonds. Journal of Political Economy, 67(3), 217-237.

Greenwood, R., \& Hanson, S. G. (2015). Waves in ship prices and investment. Quarterly Journal of Economics, 130(1), 55-109.

Gu, Z., \& Kim, H. (2002). Determinants of restaurant systematic risk: A reexamination. Journal of Hospitality Financial Management, 10(1), 1-13.

Hamada, R. S. (1972). The effect of the firm's capital structure on the systematic risk of common stocks. Journal of Finance, 27(2), 435-452.

Hong, G., \& Sarkar, S. (2008). Commodity betas with mean reverting output prices. Journal of Banking \& Finance, 32(7), 1286-1296.

Hsu, L. T., \& Jang, S. (2008). The determinant of the hospitality industry's unsystematic risk: A comparison between hotel and restaurant firms. International Journal of Hospitality and Tourism Administration.

Jarvela, M., Kozyra, J., \& Potter, C. (2009). The Relationship Between Market And Accounting Determined Risk Measures: Reviewing And Updating The Beaver, Kettler, Scholes (1970) Study. College Teaching Methods \& Styles Journal, 5(1), 1-9.

Jensen, M. C. (1986). Agency Cost Of Free Cash Flow, Corporate Finance, and Takeovers. American Economic Review, Vol. 76, No. 2, May 1986.

Kalouptsidi, M. (2014). Time to Build and Fluctuations in Bulk Shipping. American Economic Review, 104(2), 564-608. Retrieved from http://www.aeaweb.org/articles?id=10.1257/aer.104.2.564

Karpik, P., \& Belkaoui, A. (1989). The Relative Relationship Between Systematic Risk and Value Added Variables. Journal of International Financial Management \& Accounting.

Kavussanos, M. G., Juell-Skielse, A., \& Forrest, M. (2003). International comparison of market risks across shipping-related industries. Maritime Policy and Management, 30(2), 107-122.

Kim, H., Gu, Z., \& Mattila, A. S. (2002). Hotel Real Estate Investment Trusts' Risk Features and Beta Determinants. Journal of Hospitality \& Tourism Research, 26(2), 138-154.

Lee, C. H., \& Hooy, C. W. (2012). Determinants of systematic financial risk exposures of airlines in North America, Europe and Asia. Journal of Air Transport Management, 24(January 2008), 3135.

Lee, J.-S., \& Jang, S. (Shawn). (2007). The systematic-risk determinants of the US airline industry. Tourism Management, 28(2), 434-442.

Levin, A., Lin, C. F., \& Chu, C. S. J. (2002). Unit root tests in panel data: Asymptotic and finite-sample properties. Journal of Econometrics.

Lintner, J. (1965). SECURITY PRICES, RISK, AND MAXIMAL GAINS FROM DIVERSIFICATION. The Journal of Finance, 20(4), 587-615.

Logue, D. E., \& Merville, L. J. (1972). Financial Policy and Market Expectations. Financial Management, 1(2), 37-44.

Melichar, M. (2016). Energy price shocks and economic activity: Which energy price series should we be using? Energy Economics, 54, 431-443.

Merton, R. C. (1974). On the Pricing of Corporate Debt: The Risk Structure of Interest Rates. The 
INTERNATIONAL JOURNAL OF ACADEMIC RESEARCH IN BUSINESS AND SOCIAL SCIENCES

Vol. 9, No. 1, Jan, 2019, E-ISSN: 2222-6990 ㄷ 2019 HRMARS

Journal of Finance.

Modigliani, F., \& Miller, M. H. M. (1963). Corporate Income Taxes and the Cost of Capital : A Correction. American Economic Review.

Park, S. Y., \& Kim, S. H. (2016). Determinants of systematic risk in the US Restaurant industry: A technical perspective. Tourism Economics, 22(3), 621-628.

Roh, Y. S. (2002). Size, growth rate and risk sharing as the determinants of propensity to franchise in chain restaurants. International Journal of Hospitality Management, 21(1), 43-56.

Ross, S., Westerfield, R., \& Jordan, B. (2009). Essentials of Corporate Finance: selected material. In Essentials of Corporate Finance.

Sharpe, W. F. (1964). 1964 Sharpe - Capital Asset Prices. The Journal of Finance.

TITMAN, S., \& WESSELS, R. (2018). The Determinants of Capital Structure Choice. The Journal of Finance, 43(1), 1-19. 